\title{
Microbial Fuel Cell, New Technologies in the Field of Green Energy and Wastewater Treatment
}

\author{
Behzad Kanani* \\ Department of Food Science and Technology, Urmia University, Iran
}

Submission: May 27, 2017; Published: June 01, 2017

*Corresponding author: Behzad Kanani, Department of Food Science and Technology, Faculty of Agriculture, Urmia University, Urmia, Iran, Email: st_b.kanani@urmia.ac.ir

\begin{abstract}
Microbial fuel cells (MFCs) are a new technology in biochemistry and biotechnology that make it possible to convert chemical energy into electrical energy through oxidation of organic materials with the help of microorganisms. Energy obtained from MFCs can be a good substitute for fossil fuels, but this option has not been realized up to the present time because it has not become economically justifiable yet. Therefore, a lot of research must be conducted to study all aspects of this proposition to eliminate its shortcomings and reduce its costs so that it can produce substantial amounts of electricity, in addition to treating wastewater, and be cost-effective for industries. This research attempted to understand MFCs, their structure and applications, and factors that influence them as a water treatment system and also as a means of generating electricity.
\end{abstract}

Keywords: Micriboal fuel cell; Anode; Cathode; Organic Loading Rate

\section{Introduction}

As new technologies, biotechnology and biochemistry are always making innovations to achieve a good ecosystem, convert pollutants, produce biodegradable materials, develop production processes and dispose of waste in environmentally safe ways [1]. During the last century, fossil fuels considerably influenced economic and industrial growth. However, these fuels cannot indefinitely support global economy, and they endanger environmental health. The world will face the serious problem of energy shortage in future. One of the useful and practical solutions for this problem is to generate electricity from renewable resources without carbon dioxide emission [2].

MFCs are devices that convert the chemical energy in oxidizable materials into electricity by bacteria. These bacteria act as a biocatalyst in the anode compartment under anaerobic conditions, oxidize the substrates, and release electrons and protons. The released electrons are transferred to the anode electrode, pass through an external circuit, and enter the cathode compartment. This passage of electrons circuit generates electricity. The MFC is a carbon-neutral system because it converts the organic materials present in the biomass into an equivalent amount of carbon dioxide gas through the oxidation process.

\section{Microbial Fuel Cell}

MFCs simultaneously generate electricity and treat wastewater containing an organic load. They can be employed to convert many species of materials, wastewater sludge, and combined sewers into electricity.

Chemical fuel cells require expensive catalysts to perform the electron donating oxidation process, while this process is carried out naturally in MFCs by microorganisms. MFCs can be designed to operate at various temperatures and create suitable conditions for the growth of microorganisms. They can utilize a wide spectrum of the so called "dirty fuels" such as organic matter (and waste organic matter) or sediments: materials that are usually of very little value. The major drawback of MFCs is their low electricity generation capacity, and making structural changes in their design, altering the physical and chemical conditions under which they operate, changing the types of microorganisms used in them, and preparing the suitable conditions for microbial growth in order to increase electron transfer from the fuel to the electrode are among measures taken to raise the efficiency of MFCs. 


\section{History}

Potter was the first to introduce MFCs in 1910, and succeeded in generating electricity by using platinum electrodes. During the 1980s, a new approach was introduced in which the intensity of the outgoing electrical current increased with the addition of electronic intermediaries to this system. These intermediaries increase the quantity of the outgoing electricity through increasing the speed of electron transfer, and play an important role in electron transfer for those microbes that lack the ability to move electrons to the anode. Marine sediments, fresh water sediments, and activated sludge are all considered rich food sources for the microorganisms in MFCs. The first practical application of MFCs in the natural environment may have happened in 2006 when marine MFCs were first used for weather reports. These MFCs received their energy from the oxidation of organic sediments found at the bottom of the oceans [3].

\section{Applications}

Energy generation is the most important application of cells. MFCs have been able to decompose huge amounts of organic matter and environmental contaminants and, in some cases, this biological treatment is far more important than electricity generation. MFCs are used in treating wastewater that has high COD levels [4], in removing heavy metals [5], and in combined systems consisting of MFCs and membrane bioreactors [6]. In a combined system of MFCs and membrane bioreactors for unused sludge, wastewater enters from the membrane bioreactors into the MFCs and then returns to the membrane bioreactors. In this system, COD and ammonia removal efficiency has been higher than 90 percent, and sludge production 5.1\% less compared to membrane bioreactor systems. MFCs have other applications: they are used in the production of biohydrogen, in pharmacy and medicine, in sensors, etc.

Wastewater including domestic and food industry wastewater (including wastewater from dairy, starch production, chocolate manufacturing, rice processing, brewery, and from meat processing industries), and also wastewater from paper recycling factories, chemical industries, and from coke production industries has been treated using MFCs.

\section{Structure}

In MFCs, microbes oxidize substrates under anaerobic conditions and release the produced electrons in the anode compartment and the protons (after they pass through the transfer membrane) in the anode compartment. Carbon dioxide gas is also released in the anode compartment [7]. The anode compartment absorbs the released electrons in a process contrary to direct burning and sends them from the anode compartment to the cathode compartment through an external connection. The microbes remove the electrons and protons from the substrates in a process different from that in which organic materials are oxidized $[8,9]$. MFCs are of two types with respect to their apparent form: single and double chamber microbial fuel cells. As shown in Figure 1, in single chamber MFCs the cathode electrode is directly exposed to air and only the anode cathode is in a chamber [7]. However, in double chamber MFCs each electrode has its own chamber, and the two chambers are separated by a proton exchange membrane [7] (Figure 1).
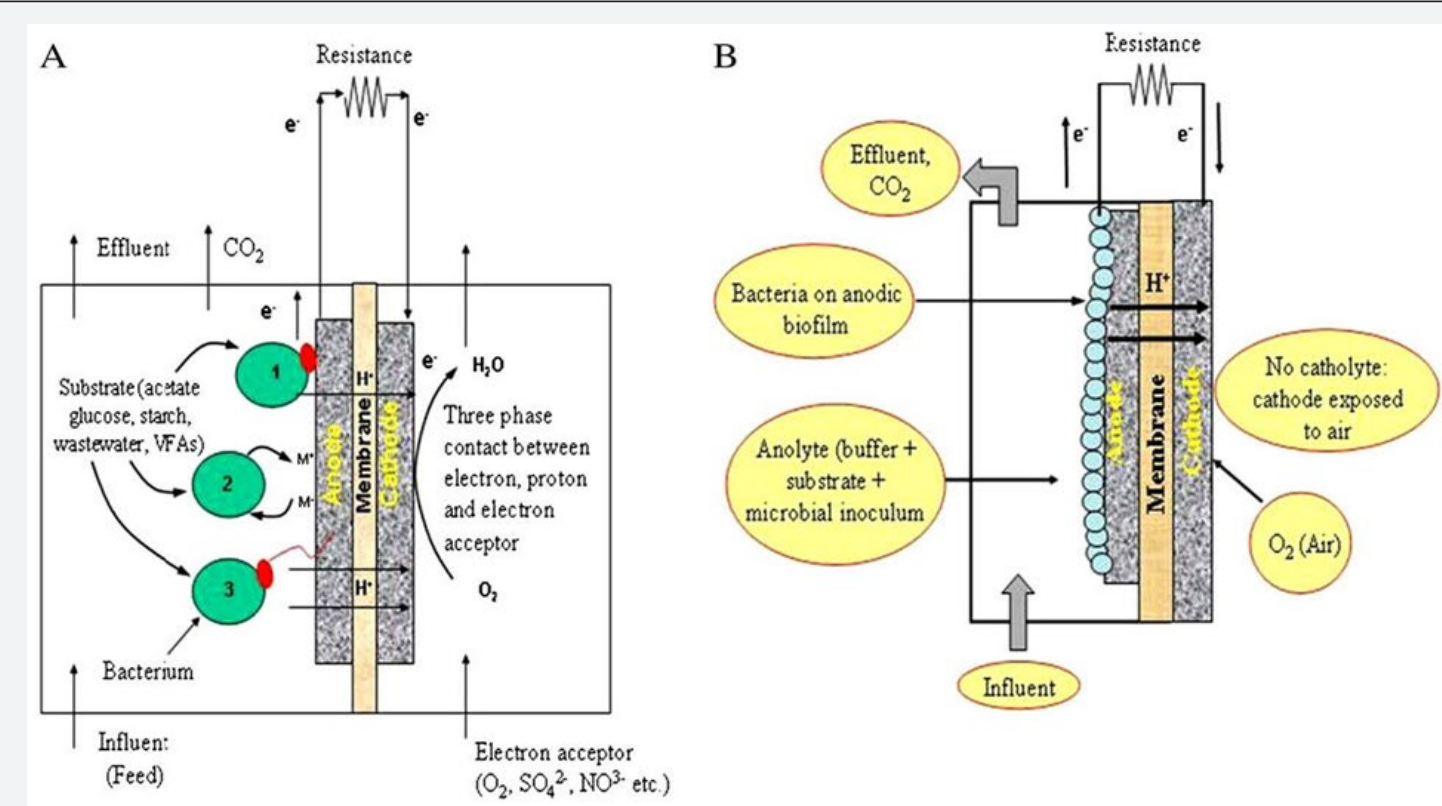

Figure 1: (A) Simplified view of a two-chamber MFC with possible modes of electron transfer is shown. (1) Direct electron transfer (via outer membrane cytochromes); (2) electron transfer through mediators; and (3) electron transfer through nanowires. (B) Single-chamber MFC with open air cathode. 


\section{The main components}

I. Intermediate materials: these materials are able to transfer electrons from inside the microbial cell membrane to the anode. Alternately, some microbes are capable of using natural intermediates such as microbial metabolites for this purpose [7]. Neutral red dye and potassium ferricyanide are two such materials that are able to improve MFC efficiency [10].

II. Proton-conductive polymer membrane: Use of Nafion as a proton-conductive polymer membrane to transfer protons to the cathode chamber and employment of its platinumimpregnated electrodes is very expensive. Zirfon membranes can be used as a substitute for Nafion [11].

\section{The main parameters}

Organic Loading Rate (OLR), the volume of incoming wastewater [12], pH $(15,22)$, and temperature [13,14] are among parameters that influence MFC performance

OLR: Increases in OLR enhances the generated electricity flow and improves sludge digestion [12].

The volume of incoming wastewater: The extent of COD removal depends on the quantity of the incoming wastewater, and COD removal decreases with increases in the quantity of the incoming wastewater.

pH: In neutral wastewater, $\mathrm{pH}$ can be observed in the range of 6-9, which is necessary for growth and activity of microorganisms $[15,16]$.

Temperature: COD removal and electricity generation improve with increases in temperature probably because of greater membrane permeability and higher levels of microbial activity [14,17].

\section{Conclusion}

MFCs are based on using green fuels and on converting their latent chemical energy into electrical energy. Therefore, various substrates including hydrocarbons, volatile fatty acids, alcohols, amino acids, proteins, and even inorganic materials have been used in this system. Egesta and real waste such as wastewater have also been treated successfully and generated suitable amounts of energy in this system. Of course, wastewater contain materials that are of different levels of bio- degradability, and the higher the percentages of materials with high levels of biodegradability are, the greater quantities of electricity will be generated. Therefore, these systems can be used in treatment plants and in factories for treating the outgoing wastewater and also for recovering part of the energy consumed by the units. This will reduce costs and, more importantly, will protect the environment. However, more applied research is needed to make this system operational and economically justifiable.

\section{References}

1. Zechendorf B (1999) Sustainable development: how can biotechnology contribute? Trends Biotechnol 17(6): 219-225.

2. Logan BE (2008) Microbial fuel cells. John Wiley \& Sons, Hoboken, New Jersey, USA.

3. Lovley DR (2006) Bug juice: harvesting electricity with microorganisms. Nat Rev Microbiol 4(7): 497-508.

4. Sevda S, Dominguez-Benetton X, Vanbroekhoven K, De Wever H, Sreekrishnan TR, et al. (2013) High strength wastewater treatment accompanied by power generation using air cathodemicrobial fuel cell. Applied Energy 105: 194206.

5. Aboutalebi H, Sathasivan A, Krishna KC, Kohpaei AJ (2011) Expediting COD removal inmicrobial electrolysis cells by increasing biomass concentration. Bioresource Technology 102(4): 3981-3984.

6. Su X, Tian Y, Sun Z, Lu Y, Li Z (2013) Performance of a combined system of microbial fuelcell and membrane bioreactor: Wastewater treatment, sludge reduction, energy recovery and membrane fouling Biosens Bioelectron 49: 92-98.

7. Du Z, Li H, Gu T (2007) A state of the art review on microbial fuel cells: A promising technology for wastewater treatment and bioenergy. Biotechnol Adv 25(5): 464-482.

8. Pant D, Van Bogaert G, Diels L, Vanbroekhoven K (2010) A review of the substrates used inmicrobial fuel cells (MFCs) for sustainable energy production. Bioresour Technol 101(6): 1533-1543.

9. Rabaey K, Verstraete W (2005) Microbial fuel cells: Novel biotechnology for energygeneration. Trends Biotechnol 23(6): 291-298.

10. Lin CW, Wu CH, Chiu YH, Tsai SL (2014) Effects of different mediators on electricitygeneration and microbial structure of a toluene powered microbial fuel cell. Fuel 125: 30-35.

11. Pant D, Van Bogaert G, De Smet M, Diels L, Vanbroekhoven K (2010) Use of novelpermeable membrane and air cathodes in acetate microbial fuel cells. Electrochimica Acta 55(26): 7710-7716.

12. Oliveira VB, Simões M, Melo LF, Pinto AM (2013) Overview on the developments ofmicrobial fuel cells. Biochemical Engineering Journal 73: $53-64$

13. Abourached C, Catal T, Liu H (2013) Efficacy of single-chamber microbial fuel cells for removalof cadmium and zinc with simultaneous electricity production. Water Research 51: 228-233.

14. Michie IS, Kim JR, Dinsdale RM, Guwy AJ, Premier GC (2011) The influence ofpsychrophilic and mesophilic start-up temperature on microbial fuel cell system performance. Energy \& Environmental Science 4 (3): 1011-1019.

15. Torres CI (2014) On the importance of identifying, characterizing, and predicting fundamental phenomena towards microbial electrochemistry applications. Curr Opin Biotechnol 27: 107-114.

16. Winfield J, Ieropoulos I, Greenman J, Dennis J (2011) The overshoot phenomenon as afunction of internal resistance in microbial fuel cells. Bioelectrochemistry 81(1): 22-27.

17. Cheng S, Xing D, Logan BE (2011) Electricity generation of single-chamber microbial fuelcells at low temperatures. Biosens Bioelectron26(5): 1913-1917. 
Your next submission with Juniper Publishers will reach you the below assets

- Quality Editorial service

- Swift Peer Review

- Reprints availability

- E-prints Service

- Manuscript Podcast for convenient understanding

- Global attainment for your research

- Manuscript accessibility in different formats ( Pdf, E-pub, Full Text, Audio)

- Unceasing customer service

Track the below URL for one-step submission https://juniperpublishers.com/online-submission.php 